\title{
"INVISIBLE PLACES, HIDDEN HISTORY": THE ROLE OF THE FORMER "RUSSIAN AIRPORT" IN TELLING STORIES ABOUT THE FRONT IN THE SOUTH VÉRTES REGION
}

\author{
István Sántha \\ Research Centre for the Humanities \\ Hungarian Academy of Sciences, Hungary \\ e-mail: istvansantha@gmail.com
}

\begin{abstract}
The South Vértes is one of the regions in Hungary where the battles between the opposing Hungarian-German and Russian sides went on for the longest period of time and were the severest. The fates of the people living in the region varied, as every village had its unique history and played a different role in the war. Moreover, individual families expressed unique attitudes in their narratives about the front, depending on whether they survived the war without major losses or suffered great traumas. The article explores stories told by local people about the "Russian airport", the only Soviet barracks established in the region after World War II, and how it was linked to the violent events of the war. While the Russian barracks in general appeared to serve as a platform for the fear accompanying the comments on World War II, different generations of local people have different positions in relation to the front and rely on different techniques for telling stories about the war. The focus is on people who were born during or just before the war and consequently have limited personal experience of the front. Members of this generation unconsciously use the "Russian airport" and its residents as a parallel platform to talk about World War II and experiences involving their families, exemplifying the complexities of communicating about the war and emotions.
\end{abstract}

Keywords: emotions, Hungary, military airport, paradox, social anthropology, Soviet block, South Vértes region, storytelling, trauma, World War II

The South Vértes is one of the regions in Hungary where the battles between the opposing Hungarian-German and Russian sides went on for the longest period of time and were the severest. Although some of the Russian troops reached German territories in the middle of March, 1945, at that time there were still military operations in the South Vértes region. The front divided the region for three months but some months before that spying and sporadic military operations were going on in the South Vértes. However, the fate of various 
people living in this multiethnic region was not always the same, as every village had its unique history and played a different role in the war. Some villages were seized by one side or the other for months, while others changed hands five or even more times. Even people from the same village often had different experiences, depending on whether they were living at one or the other end of the village. While fieldwork conducted at the end of 2015 and the beginning of 2016 took us ${ }^{1}$ to several Hungarian and two Swabian villages, and we also encountered individual Jewish families everywhere in the South Vértes, little is known about whether this multiethnic picture of the region had any influence on the actions of Soviet soldiers ${ }^{2}$ against the inhabitants of these villages. When telling stories about the front, individual families expressed different views depending on whether they survived the war without major losses or suffered great traumas.

The aim of this article is to investigate the role of the former "Russian airport" in the life of the region and local people. ${ }^{3}$ The "Russian airport", to use the local term, was a military complex comprised of three objects: an airfield built during World War II, the Russian barracks, consisting of various buildings, and the "radar station", which was used for officers' and pilots' recreation and included sleeping quarters, a Russian sauna, and a landing area for helicopters. The significance of this research topic is emphasized by the fact that the "Russian airport" was the only Russian barracks in this war-stricken region. This will be of importance when examining the relations between the violent events of the war and the Russian barracks. While this connection may seem trivial, it deserves attention because it was introduced not by researchers, but by the local people who unconsciously pushed the conversation in this direction. Although the primary function of the barracks was to be invisible (and inaccessible), my fieldwork indicates that it existed in the lives and minds of local people and it has been part of the local cognitive map. Every day, when people took the road to the county seat, they passed by the barracks and saw signs of the Russian presence. This led to some people recalling World War II memories that they immediately had to suppress. In this way, the Russian barracks became a platform for the fear accompanying comments on World War II. ${ }^{4}$

Members of the older generation with first-hand experience of the front did not need a landmark that would make it easier for them to express their emotions: if they were willing to talk about events on the front, they could directly recall their own experiences and memories. In their case we could at most say that talking about the collective traumas caused by events on the front provided a way for them to talk about deeper individual traumas. Individuals born during or just before the war had fewer personal experiences and unconsciously used the Russian barracks (and their residents) as a platform to talk about World 
War II events and experiences involving their families. Members of this generation talked about the Russian barracks and the war events with the same intensity. To be able to find a framework for understanding these fundamental motivations, we need to know the unwritten history of these villages, the history that is only passed down orally. Members of the generation born between 1946 and 1956, who came into contact with the Russian barracks because of trade or for some other practical reason, were able to talk to younger generations and outsiders about the facts but not the emotions connected to the war experiences of their families.

\section{SOUTH VÉRTES CONTEXTS}

In the following section, I would like to briefly describe the history of the "Russian airport" and discuss some of the problems related to it. It must be pointed out that the significance of the presence of Russian troops in the region after World War II is difficult to explain, as it only became more discernible towards the time of their departure, in 1991. The beginning of the history of the "Russian airport" is rather obscure. Everyone (including József K., one of the local builders of the Russian barracks) has his or her own personal story and experience of when they met the Russian soldiers for the first time after World War II.

Significantly, the area had military functions even before the "Russian airport" was established, as it was used for military training between World War I and World War II. In terms of infrastructure, the area was then favorably located. Both the nearby bauxite mine and the narrow-gauge railway used for transporting the bauxite became strategically important in the course of the war. Moreover, during the war, the Hungarian state established a Polish camp near the later site of the "Russian airport" for Polish soldiers who had escaped from Poland after the beginning of the German occupation. To this day, maps refer to this valley as the "Polish camp" (Lengyel tábor). The airfield was established during World War II and became the reserve airport for the Budapest airports of Mátyásföld and Budaörs. Among others, the family of the Earl of South Vértes and the daughter-in-law of the governor of Hungary, Miklós Horthy, escaped through this airport and negotiators taking part in secret negotiations with the Soviet Union also left through it in August, 1944 (Romsics 2003 [1999]). After World War II the airport was out of operation for a while and only Hungarian signalers appeared there from time to time. Hungarian troops were said to have served at the airport until 1954. Thus, we should note that after World War II there was no permanent Russian military presence in the region until right before the Hungarian Revolution of 1956. 
This 1956 uprising, similarly to the 1968 events in Czechoslovakia, provided the Soviets with an excuse to reinstate and stabilize their military presence in Hungary. Occasional earlier post-war Russian appearances in the South Vértes region can be considered premonitory signs of the events of 1956. Similar trends occurred in 1968 and together they help us interpret changes triggered by these two historical events. Furthermore, before 1956, the reserve nature of the airport meant that it was in temporary use and occupied sporadically. After 1956, processes accelerated, and with the events of 1968 the need for a permanent presence was clear. From the point of view of the communist leaders, the events of 1956 and 1968 explained the usefulness and necessity of the Russian military presence in the region. Before 1968, the Russian barracks consisted of only one building, with soldiers living in tents. The other buildings, mostly still in existence today, were erected between 1966 and 1968 by the South Vértes ktsz, a small industrial co-operative. The radar station on the hill was established in 1968 and served mostly recreational purposes. Another sign of development and stabilization was that the runway was paved and a helicopter landing and parking area was also established. The "reserve" status of the airport, a continuation of the situation in World War II, was changed to a "combat" status during times of armed conflict. In 1956 nothing much was happening in the region. This apparent peace enabled forces in the area to leave for other regions, "hot spots" (as in 1968, when the airport was one of the military pooling bases in Hungary for transit to Czechoslovakia).

We can only briefly summarize the events of 1956 in the region, which is sufficient because others, such as Péter Antal Polgár (2007), have published thorough studies on this subject. Given the foci and anthropological methodology of the present paper, it is important to note that the prevailing mood in the region was characterized by moderation, opening up and establishing ties with the outside world and breaking out of isolation. There were two armed incidents in the region. Interestingly, in one of the Swabian villages it was foreign miners who generated revolutionary action (ibid.). In the other Swabian village, there was an armed conflict between people fleeing from Budapest and Russian forces who were helped by the Hungarian secret police force (ibid.; also my own research).

The peculiar nature of the region can be seen in connection with the events of 1956. In critical historical moments, a contiguous mountain range with its forests provided hiding places for those fleeing from persecutors. For example, people from Csákvár, once a residence of local earls and now a small city of regional significance, who took an active role in the militia in Székesfehérvár, the county seat, hid for months in the nearby vineyards (my own research). Beyond these historical events of local importance, villages of the region took 
part in supplying food to revolutionaries in Budapest. Any kind of long-lasting activity (such as involvement in the militia or in revolutionary committees) occurred only in the centers, i.e. in county seats. A scenario more typical for the villages of the area was to take advantage of the temporary situation by destroying Russian military memorials ${ }^{5}$ or, mostly in Swabian villages, to emigrate. Generally, the mood in the bauxite mines located in the region was moderate (Nagy 2002). The desire for revenge, which there was no trace of in recollections or documents, was suppressed and stayed underground. Two more comments should be made in connection with the situation. The first is that the effects of (criminal) atrocities and political motivations were elusive in the feelings of the local people. The other is that retaliations after World War II and 1956 were mixed in memory: people were not able or not willing to separate them in their recollections. ${ }^{6}$

\section{SOURCES AND THEORETICAL BACKGROUND}

An important feature of the present research is the complete lack of written sources. I could find neither Hungarian nor Russian archival (printed or handwritten) materials about the South Vértes barracks. This is not surprising, as the Russian barracks were secret military objects. Although there were no archival traces of the South Vértes barracks, some surprising material about the region can be found on some Russian websites (e.g. Obobshchennyi bank dannykh "Memorial"). ${ }^{7}$ This includes the most complete list of Russian soldiers who died in World War II, including the locations where they perished, their names, places and dates of birth, a list of Russian war memorials with photographs and information on how they were renovated, and the correspondence of former Russian soldiers who later, as tourists, returned to their former barracks to photograph and document any changes in the buildings and to refresh their memories of the distant past.

The lack of usable maps is a general problem, and this is also a consequence of the military nature of the region. The secrecy of a military training center or an airport is of utmost importance. Especially in times of war or military conflict, such as a revolution, counter-revolution, civil war or even the possibility of these actions, secret information becomes precious, even though in times of peace this secrecy might seem superfluous to members of the civilian population. ${ }^{8}$ That being said, it is obvious that the present research can only deal with collecting folklore and storytelling. The plan was to find local elders, witnesses and other people who took part in the events, and to persuade them to talk about their encounters with Russians. 


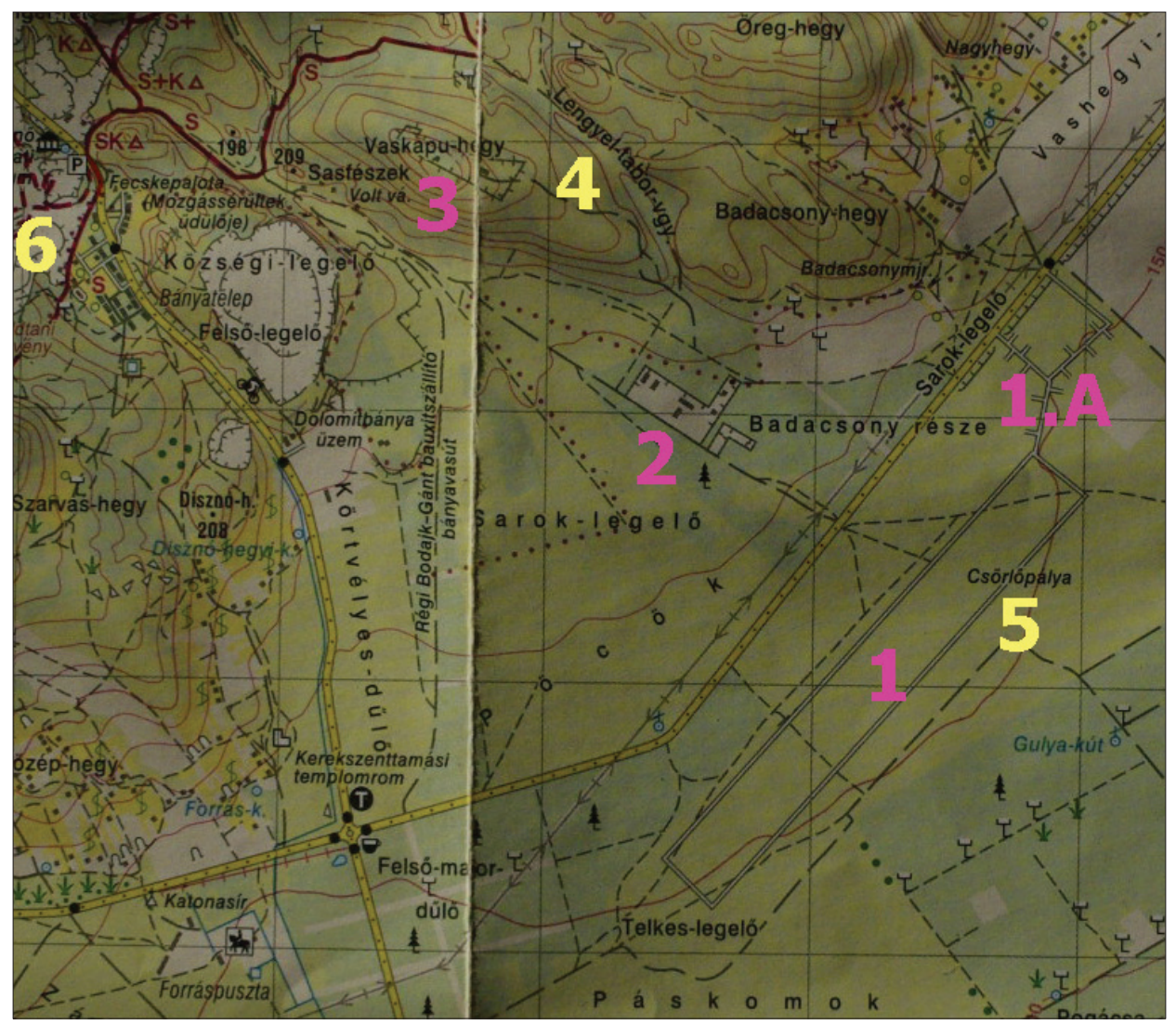

Figure 1. Map of the neighborhood of the former Russian military complex: 1 - airfield; 1 .A - helipad; 2 - Russian barrack; 3 - radar station; 4 - Polish camp; 5 - winch track; 6 - bauxite mine. Photograph by István Sántha, January 2017.

The object of this study, a former "Russian airport" that serves the local people as a symbolic space for working through their emotions, raises the significance of Marc Augé's notion of "non-places” (1995; 2002) (Fig. 2). The concept of non-places originates from Pierre Nora's idea of "places of memory" and in a more general sense from contemporary French philosophy and urban studies, reinterpreted by Augé by means of anthropological frameworks. Augé's philosophy of anthropology is in opposition to conventional history as well as to social science and anthropology. His concept is based on the crisis of meaning. According to his interpretation, there are places (he calls them "non-places") concerning which it is meaningless to attempt to build identity, create history, decode symbols or interpret relationships. Examples of non-places for Augé are the Paris subway, airports, and other modern places. 
The Role of the Former "Russian Airport" in Telling Stories about the Front

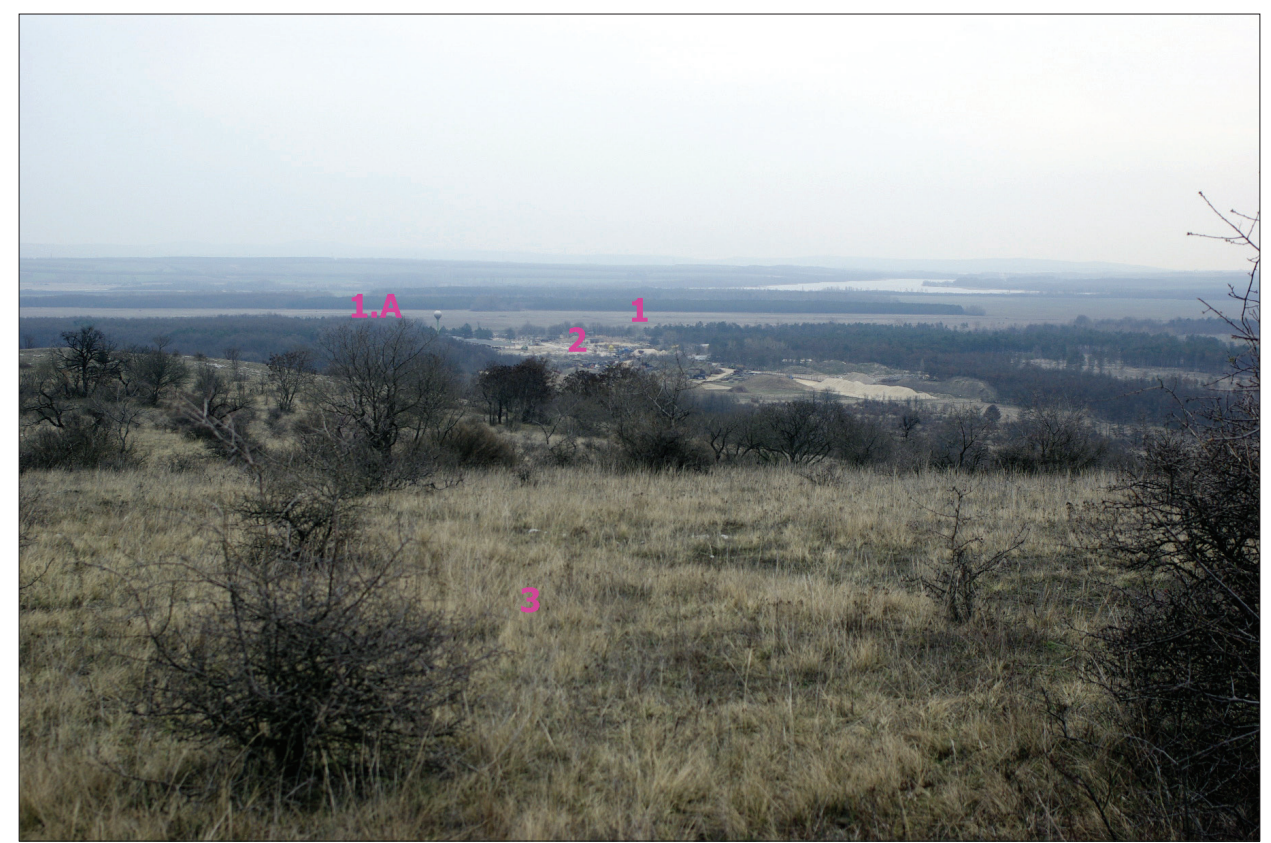

Figure 2. Landscape of the former Russian military complex: 1 - airfield; 1.A - helipad; 2 - Russian barrack; 3 - radar station. Photograph by István Sántha, March 2016.

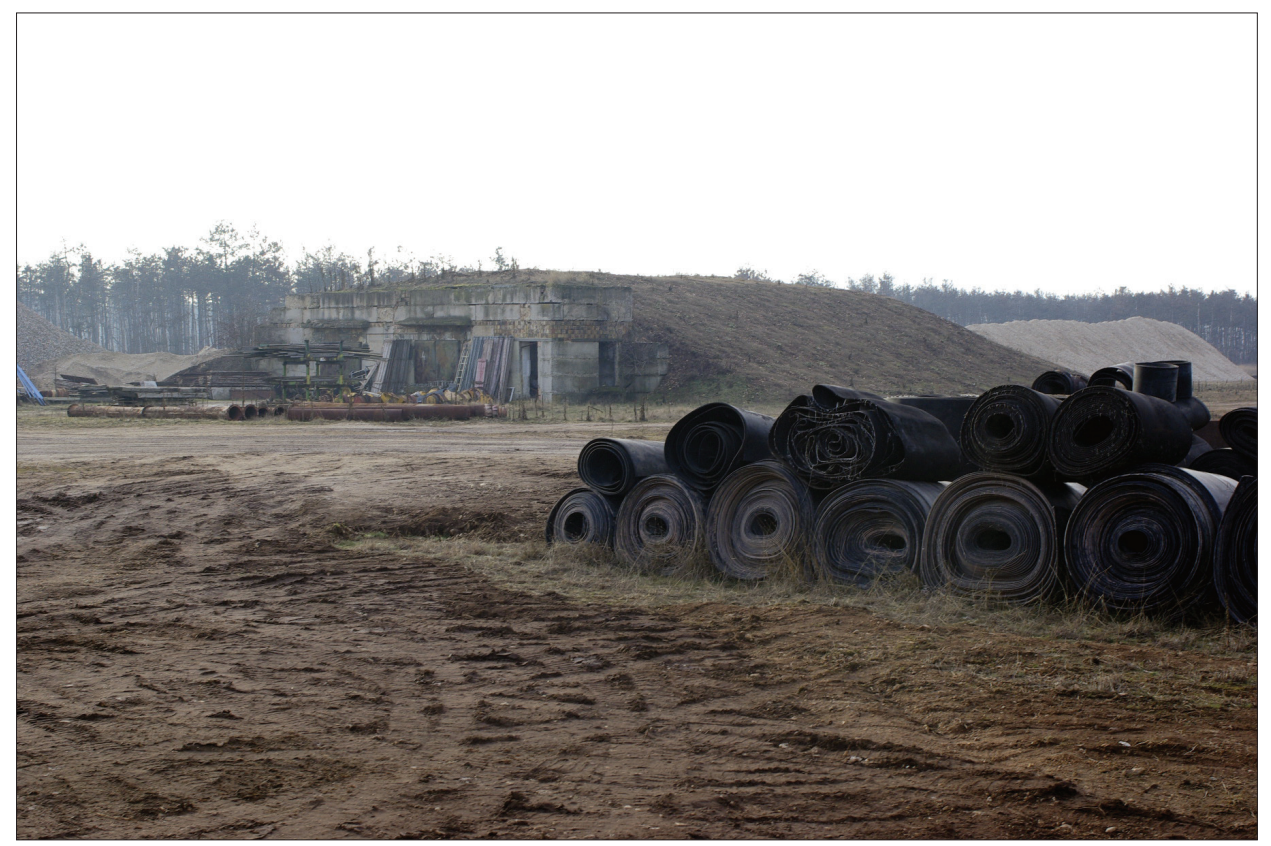

Figure 3. Bunker in the territory of the Russian barrack. Photograph by Istuán Sántha, November 2015. 
It should be noted that the lack of points of reference is significant because the object of this study is a secret military area. The question is how to construct history if there are no points of reference for storytelling. Yet, in the course of this research it was possible to find points of reference that might help us to apply historical infrastructural considerations. In this way we have the opportunity to create a "little history", a microhistory, of a particular place in a particular historical moment, without aiming to relate to the "big history". And yet, the question arises as to whether that makes sense at all, if due to the nature of the object (military, hidden, with an occupational function), invisibility and being outside of history were significant aspects of the Soviet military object. The airport was also invisible because it belonged to the military reserve; it did not belong to any of the larger barracks of the neighboring regions, but was directly subordinated to the Soviet Air Command, and this also meant that only a few soldiers served there (three officers and from ten to fifteen private soldiers). Of course, in practice things were somewhat different. Primarily hidden objectives were also revealed in 1956 and 1968, when the airport was changed from reserve to combat status, and, as a result, became more visible.

\section{LIZI'S STORIES}

The owner of the pub in the village nearest to the Russian barrack in the South Vértes region, the elderly Lizi (born in 1942), was sitting at the table across from the entrance when my friend and I, finding shelter from a heavy rain, entered the pub. The previous day, as I was doing research for a study exploring the history of a bauxite mine (Nagy 2002), I came across the unusual name of a friend from high school. When I called my friend's attention to this, he asked me if I could help him unravel the story of his grandfather, who had worked as a mining engineer in that mine before World War II. I thought that the best way to gain information about my friend's grandfather would be to see an elderly man who still lived near the site of the mine. When we tried to see him at his place, we learned that on Sundays he went to the village cemetery close to the mining site to visit the graves of his relatives. We went to look for him at the cemetery but found neither him nor his car. We decided to stay around, hoping he would turn up after the rain had stopped and that is how we ended up at the village pub.

My parents were acquainted with Lizi's mother. I first met Lizi personally in January 2016. Since then I have seen her from time to time when I visit the village. As we were inquiring about my friend's grandfather, she mentioned that she had personally known my friend's father, but she knew nothing about 
his grandfather. Seeing that the conversation would not provide any further information, and taking advantage of the opportunity, I asked Lizi and my friend if maybe we could talk about something else. I told Lizi that I had been doing research on World War II, and that I had visited the village recently. I even told her that, although more than half of the men living in the settlement belonging to the village were killed by the Russians (eleven adult males out of a total population of fifty-two), based on my experience so far, I had come to the conclusion that, compared to the surrounding villages, the village had survived the hardship of the war without major difficulties.

Lizi, however, saw it differently. She told us how Russians had taken away her aunt by force and kept her in a cellar for three days. After the war her aunt emigrated to the United States, but even as an old woman she was unable to get over the terrible things that had happened to her during the war. Lizi was very upset and her voice was shaking with anger while she was telling the story of her aunt.

Then, all of a sudden, Lizi started to tell stories about the Russian soldiers stationed in the region after World War II. There was the same anger in her voice when she spoke about the "ugly" ways the Russian officers treated the private soldiers. As an illustration, she told me two stories, both of which were in connection with her mother, Mári.

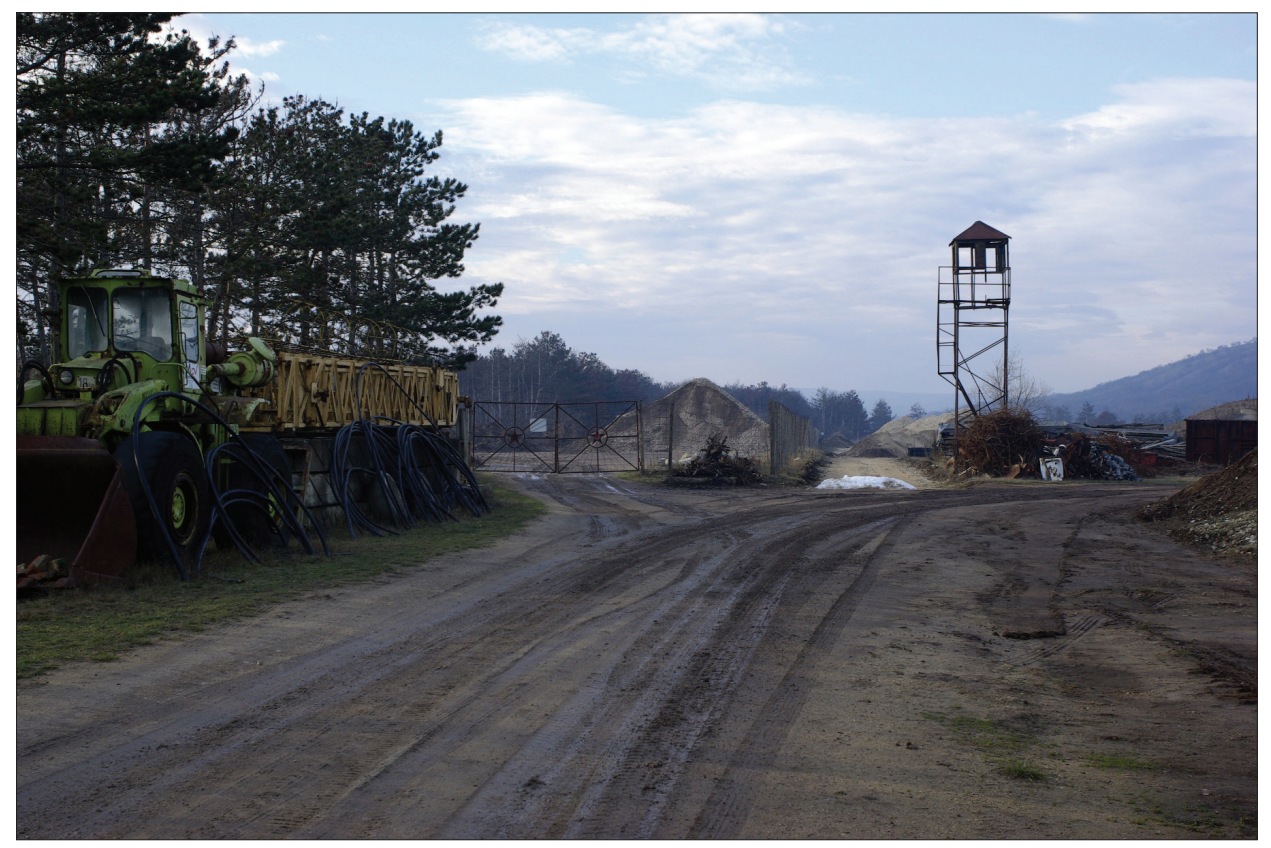

Figure 4. Russian barrack. Photograph by István Sántha, November 2015. 
In the first story, Mári felt sorry for a few soldiers standing outside in freezing temperatures and wanted to give them pastries. When the officers drinking in the warm village pub saw this, they did not like it. One of the officers, noticing that Mári was trying to outfox them, took the plate with the pastries, threw it on the ground and even stomped on it. "They are not human beings," said Lizi, reflecting her feelings about the atrocities committed against her whole family.

The second story is about a Russian soldier who once took a bedsheet to the village pub in order to exchange it for cigarettes. Seeing that the bedsheet was used and that it was probably the soldier's only one, Mári took pity on the soldier lad and gave him cigarettes without accepting anything in return. At this point, in the street she saw a Russian officer who was obviously chasing the soldier. Overcoming her fear, Mári hid the soldier in one of the rooms of the pub. The officer noticed the soldier's feet sticking out under a curtain. While Mári distracted the officer, the soldier escaped through the pub's back window and ran through the adjacent forest, straight to the barrack. The officer got into a UAZ (Russian military jeep) and taking the paved road around the forest, drove to the barrack. Mári could only hope that the soldier arrived there first. This event made Mári very upset.

After some time, a Russian officer came looking for Mári in the pub. Lizi insisted that her mother was ill and confined to bed. Realizing that the officer would not give up on the matter, they got very frightened. With the help of a translator, another Russian soldier, they learned that the officer had been re-assigned and so he had come to say goodbye and express his respect for Mári's bravery in helping the soldier escape.

Figure 5. Watchtower in the territory of the Russian barrack. Photograph by István Sántha, November 2015.

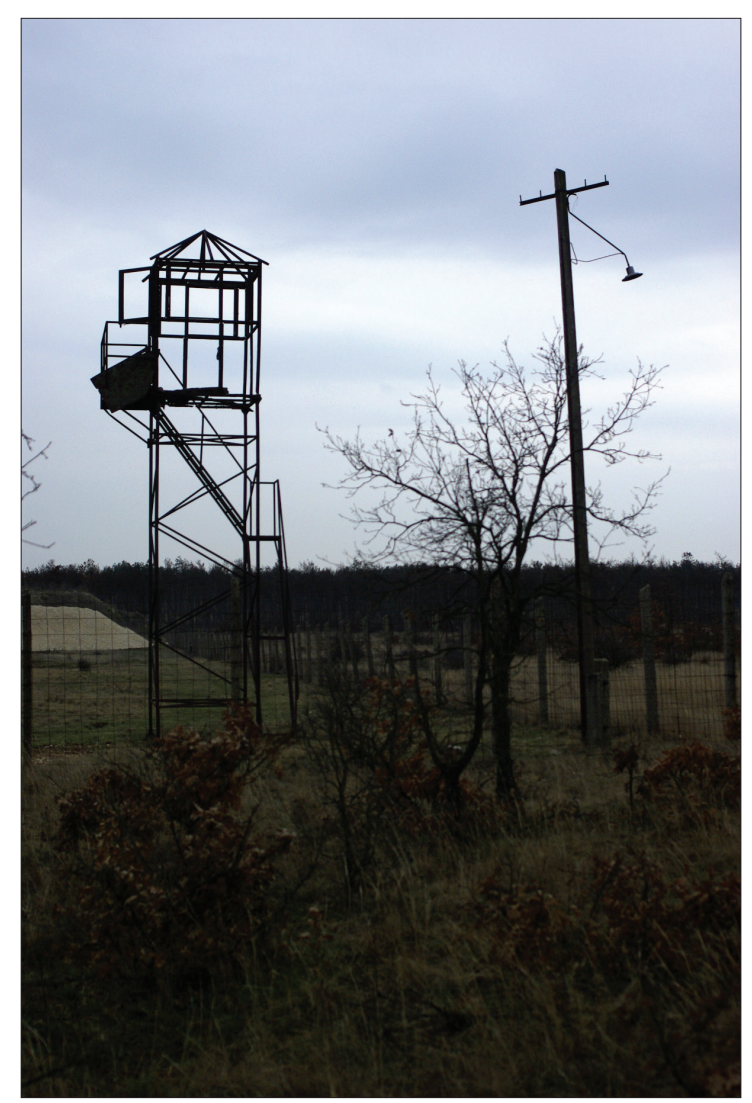




\section{STORYTELLING TECHNIQUE}

One of the main methodological approaches applied in the present research concerns storytelling. As Tatiana Safonova and I have already pointed out in our earlier research on Siberia (Safonova \& Sántha 2013), explaining communication is a complex task that requires a flexible approach. In order to interpret communication processes, we have to uncover those meta-messages that are involved in the communication process. In order to understand each other, we have to transmit not only content but also messages about how to interpret content: the meta-message is the information needed to interpret the framework. ${ }^{9}$ Passing on information about culture can happen not only through the transmitting of knowledge from one generation to another (i.e. in the form of storytelling) but also through developing the capability of telling stories. Only the successful transmission of these capabilities can ensure understanding (Sacks 1992). Telling and interpreting stories are two-way processes, based on how stories are experienced (Sántha \& Safonova 2011: 124).

Furthermore, it is worth considering what we experienced during our field trip to Siberia, namely that remembering and storytelling are complex processes that not everyone is capable of mastering. The shaman formulates what he sees through his own cultural concepts or through signs sent to him by his ancestors. The shaman's own experiences and his commentary are also part of the ritual (emotional involvement). The shamanic ritual is a practice that controls the process of remembering. The shaman is a specialist who can restore and interpret lost memories. From the shaman's perspective, storytelling is a shamanic ritual that serves practical considerations; it is the endless retelling of his own biography based on legends about the ancestors. The tragedies and dramas preserved in legends are supported by his own experiences of risky situations. During rituals, as a shaman he behaves according to the traits of his ancestors. It is the capacity of every shaman to present a personal biography through risky situations. Risky situations (traumas) need to be experienced and have to be talked about in order for them to intertwine through shamanic practices as, according to the Siberian Buryats, to talk about something does not entail less risk than to experience it in practice (Sántha \& Safonova 2011: 152-153).

Narratives about ancestors mainly revolve around risky situations, dramas, and tragedies (traumas). Incorporating a personal risk experience into knowledge about ancestors, narratives and storytelling boost an individual's reputation in the community. This emphasizes the importance of remembering as the essence of Buryat culture (Humphrey 1979). For Buryats, to remember means to integrate one's own experience into the legendary history. Historical knowledge about ancestors creates a filing system or catalog for people in the 
present to make sense of their experiences and stories. Thus, the greater the individual knowledge of ancestral history, the richer the repertoire of personal memories. Furthermore, only those with such knowledge can inherit the nature (characteristics) of ancestors and can relate an autobiography. The shaman interprets stories through the spirit helper of his family (one of the ancestors). He can remember and retell the whole story only because the situation has been resolved through the assistance of ancestors (this is a sign that the situation was dangerous). As the shaman possesses the most extensive filing system of knowledge about ancestors, he bears the richest autobiography in his local community. His "memories" are the basis upon which rituals are conducted for those who do not possess the needed knowledge and skill to construct their own biographies and to reflect on their personal experiences (Safonova \& Sántha 2010: 10).

When Lizi was interpreting family stories, this reminded me of the way Buryat shamans evoke stories about their ancestors. The fact that the stories in both cases are related to tragic events emphasizes the significance of the emotional aspect of storytelling. The knowledge of stories is not based on personal experiences, and the storytellers are emotionally involved in situations connected with relatives; these are common features in both cases. The emotional involvement in a story about which the teller does not have personal recollections (the teller was too young to remember) creates a special perspective to tell the story and analyze the teller's own biography through stories of others. These story appropriations and a form of knowledge transmission look similar in cases of shamanic narratives from the west side of Lake Baikal and recollections of war stories of inhabitants of South Vértes.

\section{THE STORY OF ANNUSKA}

Earlier, I did research on the large number of cases of sexual violence committed against minors during the war in the South Vértes region (Sántha 2016). In doing research on this topic, I was also motivated by the fact that there were fewer and fewer victims and witnesses of these incidents who were also willing to talk about their experiences and observations. While doing this research, I came to the conclusion that the front was the most serious trauma a person could experience in his or her life. However, I was wrong. The story of an old lady, Annuska (born in 1920), called my attention to the fact that talking about a certain trauma can open the door to talking about other traumatic events.

It was one of the family members who called my attention to the fact that the ninety-six-year-old Annuska was a victim, and they suggested that I should 
ask her about what she did and what happened to her during the period the frontline remained in the region. During our conversation, I could picture her as a young woman left alone by her husband who was away defending his homeland. She moved with her one-year-old son from settlement to settlement, fleeing from the Russian army. Annuska gave a detailed account of her horror when the Russians unexpectedly appeared in one of those places. And yet, she kept trying to find opportunities to change the subject and the context of the conversation to be able to talk about the fate of her son, how he was murdered at the age of forty. ${ }^{10}$ At first I tried to determine the connection, this shifting of the topic, but later I was impressed by the shifting itself as a storytelling technique. During our several encounters, Annuska used this technique several times to shift between the same topics. I thought then that the story of the rape, being a public one in the sense that it was a trauma shared by the greater public, opened up a path for talking about a very private personal trauma. Then I also started to pay attention to the use of the same shifting technique in the stories of others, but Annuska gave me the first lesson on shifting. As a next step, it seemed that it was not only possible to have connections between different traumas but a trauma could also be sustained through other topics not connected to any traumas. On second thought, we cannot ignore, as in the case of Lizi that, although for the outside listener the second traumatic event might not have appeared to be traumatic at all, it carried trauma for the victim; Mári fearfully hid from the Russian officer when he wanted to meet her in person.

\section{FRAMEWORKS FOR INTERPRETING LIZI'S STORIES}

Returning to the two stories told by Lizi, it should be noted that their content suggests that all kinds of contacts between the occupying Russian soldiers and the occupied Hungarian civilian population were forbidden. Still, in practice, the example of the Russian barrack indicates a hierarchically organized Russian society in which officers tried by all means to control the development of relations between the soldiers and the local civilians. We can apply this as an approach when interpreting the behavior of the Russian soldiers during the period the frontline remained in the region. For example, in the life of cellar communities $^{11}$ the presence of a Russian officer provided protection against the violence of soldiers.

This did not automatically mean that it was only the officers who could have had contact with civilians, even though the practices of the occupiers after World War II indicate this. The idea behind this way of organizing society could have been to reduce spying and to prevent people from obtaining any 
information about the operation of the Red Army. As I indicated in my previous study (Sántha 2016), this was the reason why between the Russian soldiers and the female population of the occupied territories any kind of relationship based on emotions, such as love or marriage, was prohibited, both for officers and soldiers (Mészáros 2014). ${ }^{12}$

The action in Lizi's two stories involving officers and soldiers serving in the nearby Russian barrack happened in the 1970s and 1980s. In connection with the soldier who escaped through the forest, we should note that Lizi knew the region around the airport because before World War I, like many other Swabian families in the village, her family had purchased land near the airport because of the scarcity of available land near the village. After the war, the land was confiscated from the family and to this day their descendants have not gotten it back.

In connection with the events that happened in the village during the period the frontline remained there, I would like to briefly note that the Swabian village nestled in the South Vértes suffered less during the war than other villages of the region. We could also add that naturally this varied from family to family, even if atrocities were committed only against one family member. As we saw in the case of Lizi, present-day descendants of some families experience and interpret these generalities differently. When I was introducing the subject of World War II and expressed my preconception that the Swabian village in the South Vértes did not suffer so severely during the war, to my surprise Lizi disagreed with this statement.

It turned out that through one family member Lizi was personally involved in suffering. While she was telling her story, Lizi automatically switched to talking about her own experiences in connection with the Russians. Her mother was the connection between the two situations she referred to. To be more precise, two members of a previous generation had had similar experiences with Russians. One was a victim and the other was a witness of the events. Lizi was too young to understand (or to remember) what was happening around her, what was happening to her relatives and neighbors. She only received impressions of the intensity of emotions. Intensity and passion created the continuity between different generations, between victims and witnesses.

The intensity of the storytelling, and the values and opinions of the storytellers were the same for family members of different generations. The decision of the aunt (who was a victim) to emigrate to Germany with the other deported Swabians ${ }^{13}$ was made partly because she believed she would be able to leave behind the things that had happened to her. Unfortunately, it did not turn out that way. Soon she decided to leave this émigré "community of witnesses" in Germany and moved on to the USA, where as an old woman she could not come 
to grips with her former experiences and broke down. In her absence, the former witness, the niece Mári (in other words, Lizi's mother) was the victim in the local community. With her values and morals, she was the one who created the connection between events of the present and the past. The present storyteller (the witness of the events of the recent past) commemorates the witnessing of terrible events and maintains the family tradition.

Lizi achieved continuity with the intensity of her opinion, which reflects the level of the terrible things committed against one of her family members. Through her storytelling, she sought continuity in the events of the family history and at the same time established a connection between two apparently different contexts. The case of Lizi made me consider the general presence of similar shifts as part of the storytelling technique. Below, I would like to discuss two more cases. In both cases, the storyteller, like Lizi, was a member of the generation born during the war but, lacking personal experiences and observations, they could authentically transmit only the experiences of other, older family members.

\section{THE CASE OF JÓZSEF K.}

I visited József K. (born in 1939) because, according to his former mason colleagues, as a technical inspector he participated in the construction of some of the buildings of the Russian barrack. As an introduction, I asked him to tell me about his first encounter with Russians. I thought that he would talk about his impressions when, as part of his job, he had first visited the Russian barrack. Quite unexpectedly, he started to talk about the war. He saw that I was surprised by this unexpected turn of our conversation. Slowly, with the help of his wife, he gathered his memories. It was difficult for him to separate his own experiences from those of other, older family members. He described how cruel members of the Ukrainian outpost were and how they did not respect anyone. He also mentioned that he remembered well the Russian soldiers (who followed the exhausted Ukrainians) relaxing in the soft grass of the embankment. Older Russian soldiers belonged to the Orthodox faith and they willingly participated in family Christmas events. Finally, he told me about an officer of Kirghiz origin who was quartered in his house and was extremely cruel to his servant, even whipping him.

I also found it strange that while I preferred the more colloquial term "Russians", József K. talked about the "Soviets". In his stories he mentioned Soviet soldiers and Soviet people. Presumably, this was important to him because in this way he could refer to Red Army soldiers of different ethnicities (Russian, 
Kirghiz, Cossack, and Ukrainian) passing through the village. It was only later that he started to talk about his actions and personal experiences at the, as he called it, Soviet barrack, which in common usage was referred to as the Russian barrack.

In his stories, József K. talked calmly and distinctly about the Soviet people, both with regard to the front and the barrack. An outsider who did not know anything about the family history would think that József $\mathrm{K}$. was unable to express his emotions and passions, and yet it was only because the family survived the war without any traumatic episodes that family matters during the war were described calmly. ${ }^{14}$

\section{DIVERSITY OF WAR TIME EXPERIENCES}

Almost every family in the region had its own trauma during the three months of the front in the region, between December 26, 1944, and March 16, 1945, when soldiers of the Red Army attacked the local population and environment. Every family, every village had its own particular position, experiences, atmosphere, and emotions connected with the front.

It is extremely important that although the region can be considered as uniform, every village had a peculiar story to tell about the front. It is important that while Lizi's family lived and still live in a small Swabian village nestled in the South Vértes, the kin of József K. lived and still live in a manor on the south-eastern slopes of the hills, a place that is now a small town of minor importance. During World War II his hometown was in a special situation as it was under Russian occupation from the first to the last day of the front, unlike other settlements that changed hands several times. On the other hand, although there were Russians in Lizi's village, the front stretched between the village and the puszta ${ }^{15}$ belonging to it. Apart from a few exceptions, the village suffered little, while terrible things happened in the pusztas. Families were often split between the village and the pusztas: some lived in the former, others in the latter. Thus family histories made and maintained a connection between the different fates of the village and the pusztas. ${ }^{16}$ In spite of the fact that life in the village was calm throughout the time of the front, several families recall their memories of the front in a tragic way because of family members who lived in the pusztas. As a result, the tragedy became a collective fate in many respects (connected with the front and deportations), even if tragic events did not occur everywhere. Some of the pusztas suffering tragedies gradually became depopulated after the war, as the part of the population that was not deported moved to the village. 
It is not only the location of a village that matters, since even within a village there were parts that suffered considerably during the front while other parts survived without significant losses. This could have happened, for example, if half of the village was evacuated by the Russians to the east and the other half by the Hungarians to the west, their respective hinterlands. In another village Russian troops invading it from the south-east caused enormous devastation in the part of the village inhabited by Lutherans. By the time the Russians arrived on the north-west side of the village, they calmed down and the Catholic population living there did not suffer or witness similar devastation. Moreover, not only villages and parts of villages (Csiga, Alvég, Tobán, Sík, Rigó, etc.) but also streets and, since sometimes a single street constituted almost the entire village, even parts of streets had their own histories. In other words, the situation varied even within villages. People had no knowledge about what happened to people at the other end of the village. Knowledge was generally restricted only to the immediate vicinity (two, three, at most five houses away) and possibly to the places where close relatives lived.

To what extent a given family suffered during the war was also determined by the location of their home, whether it was centrally or peripherally located. Another important factor was the infrastructural opportunities that the Russians saw in a certain place or object or how they thought they could make use of the individual capabilities of certain people. The central location of an "office" or the availability of a spacious room for the commander were important considerations for choosing a location for command. The hosts were expelled to the stable or the cellar, but in return all of the family members enjoyed protection. The camp kitchen was installed in a spacious yard and local people worked there for food and protection. A veterinary hospital for horses was established on the outskirts. Being an interpreter was also valuable. The life of many depended on their positions within the community of former World War I prisoners of war or whether they had been persecuted as possible holders of communist views.

It was not always the result of force when someone was helpful to the occupying troops. Experiences in the rural operation of the arrow-cross movement (the redistribution of valuables confiscated from the Jews) formed the behavioral mechanisms of some people.

There were some who, out of self-interest, were willing to serve the Russian troops. They hoped to get valuables (personal belongings, luxury clothing, etc.) confiscated by the Russians from others. Others were fearful of the dangers threatening their families, and sacrificed themselves and were willing to make compromises that they would have otherwise fiercely opposed. With these deeds, sometimes even unconsciously, they saved the lives, the health or the integrity of several family members and neighbors. 
Often these situations were so complicated that they can only be interpreted as "accidental", "luck" or "fate". One of the reasons for this is that details are generally known only to members of the local community. This local community can be an area, a village, part of a village, a street, part of a street or even a group of people or a family who found shelter in a cellar. In this connection, we can, for example, think of the fate of a settlement belonging to a Swabian village, where half of the male population perished on March 15, 1945, when the front passed through the region. Contrary to the public view propagated by local politicians, survivors' reports do not describe executions or deliberate destruction. We have to add that the above statements are also supported by the fact that the atmosphere created by deportations after the war and the permanent presence of Russian troops in the region suppressed any possible discussion of those events. On the other hand, very few people have survived who are knowledgeable members of these communities and could talk about these events in the region.

Only with the considerations of the diversity of war time experiences discussed above in mind can we interpret the motives of the three families and their feelings towards the Russians. Lizi's anger towards them was rooted in the humiliation suffered by one of her family members during the war. She used the same tone of voice when talking about the cruelty of the Russian officers towards the Russian soldiers. The Hungarian civilian population usually sympathized with the soldiers rather than the officers. It is also important to note that this was a balanced view that was usually typical of the mentality of the local population since their sympathy for the soldiers was balanced by their antipathy towards the officers. ${ }^{17}$ In contrast, József K. talked about the Russians in a moderate and neutral tone and this included events during the period the frontline remained in the region as well as those that he experienced later in the Russian barrack. László K. had no anger towards the Russians, as his father was a prisoner of war in France where he had a paid job working on a farm. He used his savings to buy a piece of land. In short, if there was positive talk at all about World War II, it was in his case, since the later success of his family was based on a transaction in which László K.'s father capitalized on his situation as a prisoner of war and made his fortune in a rural environment that suffered from shortages after the war. 


\section{THE CASE OF LÁSZLÓ K.}

My reason for visiting László K. (born in 1943) was that after the war his father established his own plant nursery by the airport, at the site of the future helicopter landing area. The plant nursery itself, as a form of private enterprise, was already interesting but I was also curious about the experiences of father and son during the times when the Russians got control of the airport, settled in, and even developed it further. At first, László K. told me about the natural conditions of the area, about the opportunities, and problems they and the Russians had to face in the proper maintenance of the airport. He told me about their work in the nursery and what he and his father grew there. He also told me about the circumstances under which they had to leave the area when the Russians appeared. They had to leave because it was felt that they could keep too close an eye on every movement of the Russians. Finally, he described in detail at what other places his father worked as a gardener later on. At this point he suddenly remarked that he had a collection of World War II artifacts that he would be pleased to show me. At first, I did not make much of this offer, even though this sudden change of topic took me by surprise.

Later, when I visited László K. to see his World War II artifacts, he filled the tops of two pig-slaughtering wooden tables with German, Russian, and Hungarian helmets, rifles, machine guns, mines, RPGs ${ }^{18}$ and other items. He added that he had more of these in the shed but he could fit only this many on

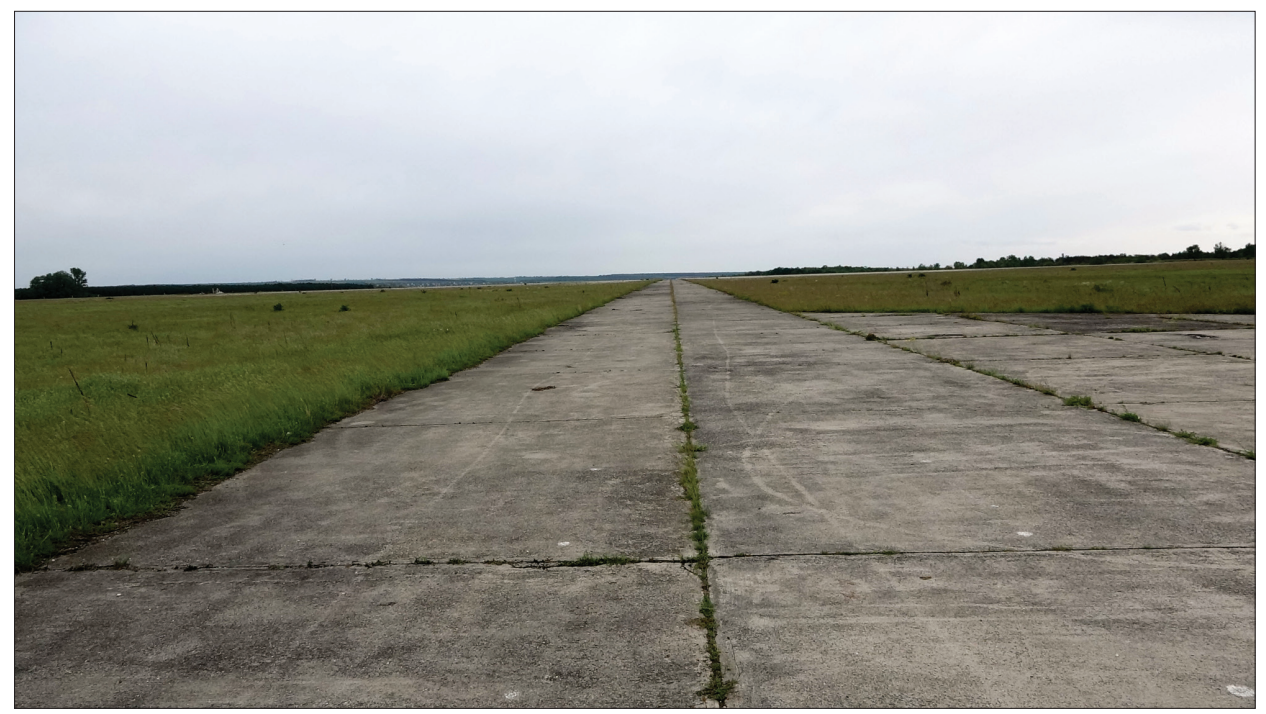

Figure 6. Airfield. Photograph by István Sántha, May 2016. 
the tables. He was telling me about the individual artifacts, which ones belonged together, and how and under what circumstances he had found them. He told me that after the $1990 \mathrm{~s}$, like some other men in the region, he had started to search the area with a metal detector in his spare time. In 2003 one of his friends asked for his help in searching for a still usable smoke mine, which they found. His friend transported the mine to his home in Csepel, in one of the southern districts of Budapest, where in his garage the mine exploded and his friend died.

Asked whether he was still acquiring new pieces for his collection, he replied that he had not gone digging for some time. After the above-mentioned tragedy, he also found a mine that started to go off at the place where he found it. $\mathrm{He}$ got lucky because only the fuse worked but not the explosive. The smoke and the loud sound frightened him. He promised himself he would give up his hobby and stop searching the area for war artifacts: he would rather live.

\section{STORYTELLING AND GENERATIONS}

As we can see, the connection between the two (Russian) contexts (Soviet soldiers in the war and after the war in the region) goes both ways, as storytellers can shift contexts in both directions. Even if they only want to describe the Russian barrack members of the same generation, they inevitably look for connections with the war. This was apparent when József $K$. recalled his faint memories of the war or when László $\mathrm{K}$. drew my attention to his war relics.

On the other hand, through these stories the folklore storytelling technique of a certain generation was revealed. An important characteristic of this storytelling is that members of the generation born during the war seek connection among different "Russian contexts". "Russian" becomes a buzzword referring to apparently very different contexts. This means that for other generations (the older generation can have conscious firsthand experiences, while younger generations have no experiences of their own and, as a result, there are no emotional effects, even indirect, in their storytelling) these barriers are either not present or these people do not need to overcome mental barriers because as the members of the post-war generation they did not live during or right after the war and could not have witnessed the destruction caused by the war, or because although they were members of the generation from before the war they did not suffer any traumas. In other cases (of the members of the generation from before the war), barriers to storytelling were almost impossible to overcome, and these people could not abandon themselves to the emotional flow of the process of storytelling. 
At this point, we have to mention the tragedy of the "generation" (if they can in fact be called a generation) of people whose very existence was connected to the events of the front: they were born from the (forced or voluntary) sexual relationships between local women and soldiers. I know of four cases in which the fathers were Russian soldiers, and some cases where local women had children with German soldiers. For some reason that is hard to determine, their mothers decided to keep the children, even though women who were raped were given the opportunity to have abortions. We can only guess the mothers' motivations for such a decision, and we cannot completely exclude the possibility that positive emotions also accompanied the otherwise sad situation. They might have hoped that their husbands and families would understand, and that they would accept the unpleasant situations since these women had suffered for their families, being subjected to the atrocities instead of them. Maybe these women did not choose to have abortions because of religious reasons or simply because their pregnancies had developed to a stage where abortion was not an option. The fact that the parents are not alive anymore makes any research on this topic hard. Family members can only pass on rumors or background information and often their emotional motivations are opposite to those of the people in question. Moreover, in the South Vértes region, people who had been born out of wedlock were rarely willing to give interviews. They ended up on the periphery of society, and sometimes they moved to locations several hundred kilometers away or lived in the local vineyard. The secrets were nearly impossible to completely uncover, as these people hesitated to talk, just as their mothers did not want to talk about the horrors they had suffered.

At this point we should emphasize the main mechanism shaping the attitude of the local population towards the Russians. Both during and after the war, the most important aspect seems to have been the rigid structure within the Russian military society. Another feature is that at both times the local population sided with one party or another. However, it is interesting that the roles switched. During the time of the front, the officers were usually positive figures; people could hope for protection from the officers from the unscrupulously devastating Russian military hordes. On the other hand, after the war it was the soldiers and not the officers with whom the local population sympathized. As in the case of Lizi, we see that the locals maintained a sort of conflict between these two strata of Russian society, even if only in their narratives, perhaps as a way to weaken the occupiers. In regard to the characteristics of this method, we also have to stress that this stratum of Hungarian society was not hostile towards the Russians: they noticed and talked about their positive features. 


\section{CONCLUSION}

In conclusion, referring to the title, and returning to Augé's anthropological interpretation of Nora's concept of place of memory (lieux de mémoire), an important issue is the role of the anthropologist if there are obviously points of reference, but they are officially non-existent and undocumented, only existent in oral communication and discourse. ${ }^{19}$ It could be a good decision, which is also a frequent anthropological approach in such situations, to simply note paradoxes without aiming to resolve them (Navaro-Yashin 2012; Pedersen 2011). In our case this means that we work on a historical topic without creating a history. It cannot be our task as anthropologists to make history visible when the purpose of constructing the object was secrecy.

We can say that by using these contexts (historical, local, and military), discussed in detail above, for interpretation we could get a glimpse of the mechanism of handing down knowledge within a family. This could be used to share stories witnessed in a peculiar way by the storytellers. However, due to the age of the storytellers at the time of the events, they could not have possibly directly remembered the events; the stories were only part of the family folklore. Every family had its own attitude towards the front and the Russians, depending on where, in which village and how they survived the critical times. There are those, such as Lizi, whose families became victims of violence. Others, such as József K., did not suffer significantly. Some people were neutral and I even met people who had positive impressions in connection with the appearance of the Russians. These motives and emotions are reflected in the way different families told their stories about other topics involving the Russians, such as the Russian barrack operating in the region after World War II.

As a result of the Russian presence in the region, in an area where every family had its own history and experiences of the war, people are still not willing to talk about these events. On the other hand, absurdly, through their contacts with the Russians they could live out these emotions and later, when the Russians left the region, it was possible to talk about these emotions in a direct way. The bond between the different Russian contexts remained. In my opinion, the mechanism of storytelling is much more complex than just who talks about his or her war experiences or who does not talk about them. It is not possible to model the mechanism of storytelling in such a simple way, but we can still get a glimpse of the mechanisms at work in the case of members of a given generation, and also of how different epochs are connected to one another in order to conceal or live through traumas. 


\section{ACKNOWLEDGEMENTS}

This article was translated from Hungarian by Tímea Takács. The article is based on research conducted within the framework of the project "History of Hungarian Countryside 1944-1990", carried out in cooperation between the Research Centre for the Humanities at the Hungarian Academy of Sciences and the Committee of National Remembrance.

\section{NOTES}

1 Here I need to explain how I have used the "I" and "we" pronouns in this article. I have used "we" to refer to previous common fieldwork or to previous common publications in collaboration with Tatiana Safonova. I have used "I" when I describe a fieldcase in which I worked alone. I have used "we" generally to involve the reader in my text, to make it feel like our common product. And finally, sometimes I have also used "we" because I want to avoid using the passive voice.

2 There were also traumatic cases with German and Hungarian soldiers, although these cases remained hidden because of the Swabian and Hungarian local peoples' empathy and solidarity with the German and Hungarian armies and soldiers.

${ }^{3}$ Among others, this also holds true for the author, for whom this region was one of the important venues of his socialization, as his parents had owned and cultivated a small vineyard two kilometers from the Russian barracks.

4 This does not exclude the possibility that the connection can be regarded as almost trivial, since Russian troops stationed in Hungary were representatives of the victorious power, and maintainers of the newly established order. They were morally responsible for the events on the front if they connected themselves to those who took part in the events on the Russian side. This is the connection that is implicitly expressed with the use of the storytelling technique. This is equivalent to the silence of the members of the previous generation or to the fact that after the 1990 s members of the same prewar generation started to talk about the atrocities they had suffered.

5 It should be noted that cautious behavior was also observed in this case, for on almost every occasion there were some who tried to save these objects or calm people down to avoid revenge or lynching. These deeds were weighed positively when accounting for the crimes committed during the 1956 revolution.

6 At the end of the 1940s and at the beginning of the 1950s, trials were initiated by local communists or their relatives against local nationalists. These trials were based on accusations that "nationalists" attacked "communists" during World War II. These trials were sometimes delayed until 1956 and continued after 1956.

7 Obobshchennyi bank dannykh "Memorial"(OBD "Memorial”): a website for documents about soldiers of the Red Army who disappeared during World War II. Available at https://www.obd-memorial.ru/html/index.html, last accessed on September 21, 2017. 
8 See also some footnotes herein about similar questions concerning the withdrawal of the Russian troops in 1991 and the lack of land registry maps of the affected regions.

9 According to Gregory Bateson's anthropological terminology, "frame" and "metaframe" (Bateson 1972; Safonova \& Sántha 2013: 12-13).

10 The two apparently unrelated traumas may be connected by motifs. One motif might be aggression, since the boy was present when his mother was fleeing from the violence of the Russians. He might have been one year old at the time, so he can be considered to belong to Aunt Lizi's generation. The other connection between the two traumatic events might have been the sexual aspect. The boy was mentally disabled from his childhood but the extent to which this was caused by the traumas he had suffered during the war was unclear. He worked casual jobs; for example, for the forestry department together with his mother. On pay days he often disappeared and later he was found among dubious figures in the county seat. He had a wife, though they did not stay together for long and did not have any children. Then he became interested in his own sex. Under unclear circumstances he was strangled by his last partner after a sexual intercourse.

${ }^{11}$ Neighbors and relatives hid from the Soviet soldiers in cellars. The members of cellar communities had symmetric or complementary positions as participant-sufferers or observer-witnesses; they and only they were truly able to understand the experiences, emotional involvements in events and atrocities.

${ }^{12}$ For similar reasons it was not a good idea if a Russian soldier captured by the enemy returned after he was released. Not only during but also after World War II, confidence in these soldiers was shaken. Former prisoners of war were not considered proper and useful members of society. People believed that they could only have stayed alive by betraying their fellows and their country, and that they may have been roped in by foreign secret services and in fact might still be working for them. This sort of suspicion was even stronger in the case of officers. When the war broke out, those who were considered dangerous to Russian society had to volunteer for service on the front, where they were used as "human shields" to provide temporary protection for other units fighting behind them. It was a general practice that victims of the Stalin repression who had been sent to gulags before the war had to return to their place of exile after their service at the front ended; they were released and could return to their families and loved ones only after Stalin's death in 1953 (see, among others, Aleksievich 2015 [1985]).

${ }^{13}$ According to presently available data, in 1946 nearly a thousand people from the village were deported. Today 600 people live in the village (Schmidt 2003).

${ }^{14}$ In connection with the absence of any atrocities in his family, when referring to the war I inquired when the first time was that he saw a dead man; it was not the war that he mentioned but the bombings before the war.

${ }^{15}$ A puszta in Hungary is the same as a steppe in Eurasia and a prairie in America. Nevertheless, the word also has another meaning: an economic farm owned by aristocrats. This connects with a more recent meaning: a couple of houses located outside the territory of the village (sometimes five to ten kilometers from each other); administratively a puszta is not an autonomous unit, but belongs to the village. 
${ }^{16}$ For example, some members of a big family lived in a puszta while other members lived in the village. Close relatives of puszta people could always be found in the village, which provided very practical opportunities for both sides. Gathering firewood and breeding animals (for example pigs) were easier from the puszta, while shopping and going to school were easier from the village.

17 The atrocities that occurred on the front were mostly committed by irregular forces, especially in the days after the occupation. In this situation, it was only the permanent presence of officers that could ensure some protection for the local population, if they were able, in some way, to gain the sympathy of an officer. This protection lasted only as long as the officer was stationed there and his authority among the soldiers was not damaged by, for example, getting wounded.

${ }^{18}$ Abbreviation in Russian for a hand-held armor-piercing grenade launcher.

${ }^{19}$ Here I need to express my special gratitude to Elo-Hanna Seljamaa, one of the editors of this collection, for supporting me in elaborating this idea.

\section{REFERENCES}

Aleksievich, Svetlana 2015 [1985]. U voiny ne zhenskoe litso. [War's Unwomanly Face.] Moscow: Vremja.

Augé, Marc 1995. Non-Places: An Introduction to Supermodernity. London \& New York: Verso.

Augé, Marc 2002. In the Metro. Minneapolis: University of Minnesota Press.

Bateson, Gregory 1972. Steps to an Ecology of Mind: A Revolutionary Approach to Man's Understanding of Himself. New York: Ballantine Books.

Humphrey, Caroline 1979. The Uses of Genealogy: A Historical Study of the Nomadic and Sedentarised Buryat. In: Equipe écologie et anthropologie des sociétés pastorales (ed.) Pastoral Production and Society / Production Pastorale Et Société. Proceedings of the International Meeting on Nomadic Pastoralism, Paris, Dec. 1-3, 1976. Cambridge \& New York: Cambridge University Press, pp. 235-260.

Mészáros, Márta 2014. A láthatatlan generáció 1-2. [Invisible Generation, series 1-2.] Budapest: Cameofilm.

Nagy, Béla 2002. A gánti bauxitbánya története. [The History of the Bauxite Mine in Gánt.] Unpublished manuscript.

Navaro-Yashin, Yael 2012. The Make-Believe Space: Affective Geography in a Postwar Military. Durham \& London: Duke University Press.

Obobshchennyi bank dannykh "Memorial". [Comprehensive Databank "Memorial".] Available at https://www.obd-memorial.ru/html/index.html, last accessed on September 13, 2017.

Pedersen, Morten A. 2011. Not Quite Shamans: Spirit Worlds and Political Lives in Northern Mongolia. Ithaca \& London: Cornell University Press.

Polgár, Péter A. 2007. Sorsom ezt így rótta ki... Történetek az 1945 és 1956 közötti idôszakból. [Inflicted by My Fate... Stories from the Period between 1945 and 1956.] Budapest: Kornétás kiadó. 
Romsics, Ignác 2003 [1999]. Magyarország története a XX. században. [History of Hungary in the 20th Century.] Budapest: Osiris.

Sacks, Harvey 1992. Lectures on Conversation, Volumes I \& II. Oxford: Blackwell.

Safonova, Tatiana \& Sántha, István 2010. Different Risks, Different Biographies: The Roles of Reversibility for Buryats and Circularity for Evenki People. Biography, Risk and Uncertainty. Forum Qualitative Sozialforschung / Forum: Qualitative Social Research, Vol. 11, No. 1. http://dx.doi.org/10.17169/fqs-11.1.1430.

Safonova, Tatiana \& Sántha, István 2013. Culture Contact in Evenki Land: A Cybernetic Anthropology of the Baikal Region. Leiden \& Boston: Brill \& Global Oriental. https://doi.org/10.1163/9789004254237.

Sántha, István 2016. A front emlékezete: A Vörös Hadsereg kötelékében tömegesen és fiatalkorúakon elkövetett nemi erôszak kérdése a Dél-Vértesben, elótanulmány. [The Memory of the Front: The Question of Mass Rape and Rape against the Youth Committed by the Soldiers of the Red Army in the South Vértes Mountain in Hungary, a preliminary study.] In: Gábor Csikós \& Réka Földváryné Kiss \& József Ö. Kovács (eds.) Váltóállítás: Diktatúrák a vidéki Magyarországon 1945-ben. [Dictatorships in Rural Hungary in 1945.] Budapest: MTA-BTK-NEB, pp. $119-154$.

Sántha, István \& Safonova, Tatiana 2011. Az evenkik földjén: Kulturális kontaktusok a Bajkál-vidéken. [In the Land of Evenki: Culture Contact in the Baikal Region.] Budapest: Balassi Kiadó.

Schmidt, Helmut 2003. Unser Schicksal: Erinnerung an die Heimatvertriebenen aus Gánt / Ungarn und den umliegenden Dörfern im Vértesgebirge bzw. Schildgebirge (Stand). Unpublished manuscript. 